\title{
Carbenicillin Indanyl Sodium
}

National Cancer Institute

\section{Source}

National Cancer Institute. Carbenicillin Indanyl Sodium. NCI Thesaurus. Code C1409.

The sodium salt of indanyl carbenicillin, a broad-spectrum, semi-synthetic carboxypenicillin antibiotic with bactericidal activity. Carbenicillin acylates C-terminal domain of penicillin-sensitive transpeptidase, resulting in opening the lactam ring of the antibiotic. This inactivation prevents the formation of the cross-linkage of peptidoglycan strands, thereby inhibiting the third and last stage of bacterial cell wall synthesis. As a result, cell wall integ rity is compromised and cell lysis may follow. This agent is used mainly for gram-negative infections, and has limited gram-positive coverage. 